\title{
表皮に含まれる脂質のバリア形成における役割
}

\section{Roles of Epidermal Lipids in Barrier Formation}

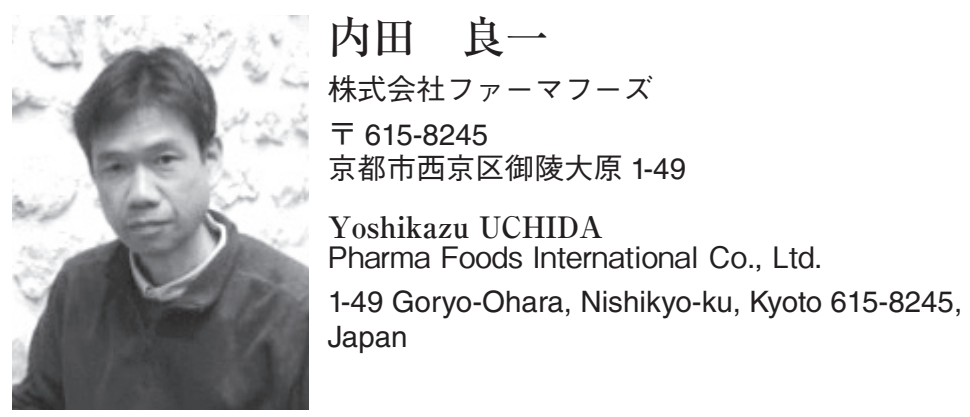

論文要旨：皮膚の最外層を覆う表皮は, 紫外線, 乾燥, 化学物質や病原微生物などの外界からの刺激を直 接受けている。これら外界の影響を軽減し, 正常な生体機能を維持するため, 表皮は, 複数種の防御（バリ ア）機能を備えている。表皮は機能的と性状的に異なる基底層，有棘層，顆粒層および角層の計四層から構 成されるが, 角層に殆どのバリア機能が集約されている。脂質は, 角層の細胞間で表皮透過バリアを形成し ている。特に，他の組織に類をみない多様な分子種からなるセラミドは，バリア形成に必須な脂質となって いる。また，セラミドの代謝産物は，セラミドと同様に表皮透過バリアの形成に関与するだけでなく，有核 の表皮層（基底層, 有棘層, 顆粒層）において, 情報伝達物質として, 抗菌ペプチドの産生を調節し, 抗菌 バリアの形成に寄与している。

\begin{abstract}
The epidermis is continuously exposed to deleterious external stimuli, such as ultraviolet irradiation, dryness, mechanical stress, xenotoxic chemicals and microbial pathogens, and it deploys multiple barriers to protect internal tissues as well as the skin from these insults to maintain normal cellular functions. The epidermis consists of four layers - stratum basale, stratum spinosum, stratum granulosum and enucleated stratum corneum. The stratum corneum deploys most barriers, and it is the lipids in the stratum corneum that play a critical role in forming the epidermal permeability barrier. In particular, in the stratum corneum, ceramide is the lipid, made up of heterogeneous molecules not reported in other tissues, that is essential for barrier formation. Ceramide metabolites also contribute to formation of a competent permeability barrier formation. Additionally, these ceramide metabolites in the nucleated layers of the epidermis serve as modulator lipids in the formation of the antimicrobial barrier through increasing antimicrobial peptide production.
\end{abstract}

Key words: skin, epidermis, barrier, lipids, ceramide

\section{1 緒言}

生体の最大臓器（重量にして約 16\%）の皮膚は, 表皮, 真皮と皮下組織（脂肪組織，皮脂腺，爪，汗腺と毛組織） から構成される複合組織である。皮膚の最外層を覆う表 皮は, 外界からの刺激を直接受ける組織であることから, 化学的, 物理的および機械的な刺激に対する防御（バリ ア）機能を備えて, 正常な生体の機能を維持している。 表皮は機能的と性状的に異なる基底層, 有棘層, 顆粒層 および角層の計四層から構成されるが, 角層に殆どのバ

連絡者：内田良一

E-mail :y-uchida@pharmafoods.co.jp
リア機能が集約されている。脂質は, 表皮透過バリアの 形成に重要な役割を負うとともに, 情報伝達物質として, 皮膚の細胞の増殖と分化調節や免疫バリアの形成に寄与 している。本総説では, 陸棲哺乳動物の表皮の脂質を対 象にして，そのバリア形成への役割を概説する。

\section{2 表皮}

表皮は, 皮内側より, 基底層, 有棘層, 顆粒層, 角層 の 4 つの層に分類される。表皮に含まれる細胞の $95 \%$ 以上を占める, ケラチノサイトは基底層で分裂し, 分化 により，有棘細胞，顆粒細胞，ついで，核が分解（脱核） し, 角質細胞となる。分化の過程で, 構造的, 代謝的, 
成分的に性状が変わる。角層には，脂質，タンパク質分 解酵素が含まれ，脂質やタンパク質が分解されるが，新 たな生合成は起きていない。表皮透過バリアは，ケラチ ノサイトにより形成される。ケラチノサイト以外にメラ ノサイトと免疫系細胞（ランゲルハンス細胞，メルケル 細胞, 樹状細胞）が含まれる。メラノサイトはメラニン を合成し，紫外線から生体を保護する役割を負ってい る。免疫系細胞は，外来異物の排除に寄与している。

\section{3 表皮のバリア}

正常な生体機能の維持には，一定な生体内環境が必要 である。これに対して, 生体外環境は, 地域, 時間, 季 節，天候などの諸条件で大きな変動を示す。以下に解説 のように表皮は，少なくとも7つのバリアを形成し，こ れら外環境の影響を軽減し, 生体内環境を一定に維持し ている。

\section{$3 \cdot 1$ 表皮透過バリア}

外来の異物（化学物質, タンパク質, 脂質, 炭水化物 および微生物）の生体内への侵入を防ぐと同時に生体内 成分の漏出を防いでいる。角層の細胞間に形成された脂 質ラメラ構造物が表皮透過バリアの役割を負っている。 さらに，有棘層と顆粒層の細胞間隙に形成されたタイト ジャンクションも物質の侵入と漏出を防いでいる。角層 のラメラ構造物は生体外に向かって細胞の上下（apical） に形成されているのに対して，タイトジャンクションは 細胞の左右（lateral）に存在する。表皮透過バリアは陸 棲と水棲では異なり，また，陸棲の中でも，哺乳類，鳥 類と爬虫類では異なる。動物に限らず, 植物の外皮 $(\mathrm{Cu}-$ ticle）もバリア機能を担っている1)。動物と植物のいず れの表皮透過バリアも脂質がバリアの中心的な役割を 負っている。植物はワックスエステルとアルカン（炭化 水素）がバリア脂質となる。これに対して，陸棲哺乳動 物の場合，セラミド，コレステロールと遊離脂肪酸が主 要な脂質成分となりバリアを形成している。

\section{$3 \cdot 2$ 抗酸化バリア}

アスコルビン酸（ビタミンC），（トコフェロール／ $\beta$ トコフェロール (ビタミン E ), グルタチオンなどの 抗酸化成分が, 角層に含まれている。角層以外の表皮層 に执いては，これらに加えてスーパーオキシドディスム ターゼ（SOD）が, 酵素的に過酸化物の分解に寄与し ている。

\section{$3 \cdot 3$ 物理的バリア}

動物の細胞は, 脂質二重層膜に覆われているが, 角層 のケラチノサイト（角層細胞）は, タンパク質が架橋し た角化不溶性膜で覆われている ${ }^{2)}$ 。角化不溶性膜は $1 \%$ Sodium Lauryl Sulphate (SLS) と $\beta$-メルカプタエタノー
ルやジチオスレイトールなどの還元試薬溶液中で，加熱 処理しても, 可溶化しない。化学的に, また, 物理的に 堅牢な構造を保ち, 機械的 - 化学的な刺激から皮膚を保 護している。

\section{$3 \cdot 4$ 紫外線バリア}

角層に含まれるフィラグリンがタンパク質分解酵素に より分解され産生されたヒスチジンから，ヒスチナーゼ により, ウロカニン酸が生成される。ウロカニン酸は, 紫外線吸収作用をもち, 皮膚を紫外線から防御してい る。紫外線照射を受けるとトランス型からシス型に変化 する。ウロカニン酸以外に, 紫外線吸収作用は, 弱いも のの他のタンパク質成分も紫外線を吸収し，紫外線バリ アの形成に寄与している。また，メラノサイトが産生す るメラニンも紫外線から皮膚を保護している。

\section{$3 \cdot 5$ 化学的バリア}

角層以外の表皮層には，肝臟や腎臟と同様に，酸化· 還元酵素と抱合体合成酵素 ${ }^{3}$ が含まれ，化学物質を代 謝する機能を備えている。

\section{$3 \cdot 6$ 抗菌バリア}

表皮透過バリアは，微生物の侵入を防いでいる。さら に, ケラチノサイトは, 抗菌ペプチドを産生し, 微生物 の浸潤と増殖を抑制している。抗菌ペプチドは, 細菌, 真菌, 植物および動物と進化的に保存され産生される自 然免疫成分の重要な因子として微生物感染から宿主細胞 を防御している。哺乳動物では, リンパ球, 好中球, 単 球やマクロファージなどの免疫系細胞に加えて，表皮を 含めた上皮系細胞で抗菌ペプチドが産生されている。抗 菌ペプチドは，陽イオン性あるいは陰イオン電荷に富む ペプチドで生体成分と親和性を持ち，細胞膜に結合ある いは融合し，膜に小孔を作る。その結果，細胞内成分の 漏出と細胞外成分の侵入により細胞機能を低下させ る ${ }^{4,5)}$ 。ある種の抗菌ペプチドは細胞内に取り込まれた 後, 宿主の核酸やタンパク質に結合して代謝機能に障害 を与える ${ }^{5)}$ 。したがって，抗菌ペプチドは菌株（ある種 の真菌・ウイルスにも作用を示す）を問わない広域の抗 菌スペクトルを示す。さらに，特定の代謝過程を阻害す る作用機構による抗生物質や抗菌剂と違い, 抗菌ペプチ ド耐性菌の発生頻度は低い。

\section{$3 \cdot 7$ 免疫バリア}

角層以外の表皮層は，異物を認識しそれを排除する免 疫機能を備えている。抗原の認識と免疫系の活性化に関 与するランゲルハンス細胞やガンマデルタ $(\gamma \delta) \mathrm{T}$ 細胞 に加えて, 毛包周囲に存在する制御性（レギュラトリー） T 細胞は過度な炎症反応を抑制する ${ }^{6)}$ 。さらに，ケラチ ノサイトは，刺激に応答してさまざまなサイトカインを 産生・放出することにより免疫反応の抑制あるいは活性 
化に関与している。

以下に解説するように, 脂質は表皮透過バリアと抗菌 バリアの形成に直接的に寄与している。

\section{4 透過バリアの形成に関わる脂質の生成}

基底細胞, 有棘細胞と顆粒細胞の細胞膜成分の脂質は, 他の組織の細胞と同様に，リン脂質，コレステロールお よびスフィンゴ脂質が主要な脂質成分となっている。分 化後期の顆粒細胞では，コレステロールと多様な分子種 からなるセラミドの産生が高まる。産生されたセラミド の殆どは，スフィンゴミエリンとグルコシルセラミドに 変換され層板顆粒 $(4 \cdot 3$ セラミド合成 参照) に蓄積 される。角層においては, セラミド, 遊離脂肪酸とコレ ステロールが主要な脂質成分であり，表皮の顆粒層，有 棘層および基底層を含めた他の動物細胞と著しく異なっ た脂質組成となる。以下に表皮透過バリアを形成する主 要な脂質成分のセラミド, 遊離脂肪酸とコレステロール の生成過程を概説する。

\section{$4 \cdot 1$ コレステロール合成}

コレステロールは, 食事から摂取されるとともに, 肝 臓で合成される。食事由来のコレステロールは，腸管で 吸収された後, リポタンパク質粒子のカイロミクロンに 取り込まれて, 肝臓に移送される。肝蔵において, 合成 されたコレステロールとともに Low-density lipoprotein （LDL）に取り込まれ体内を循環する。ケラチノサイト は, 膜に LDL 受容体を発現し, コレステロールを細胞 に取り达むが，ケラチノサイトもコレステロールを産生 し, 細胞の膜と表皮透過バリアの形成に寄与している。

コレステロールの合成は, アセチルコエンザイム $\mathrm{A}$ (ア セチル -CoA）アセチルトランスフェラーゼによる，ア セチル - CoA からのアセトアセチル - CoA 生成を出発と して開始される。次いで 3- ヒドロキシ -3-メチルグルタ ミル - コエンザイム A (HMG-CoA）合成酵素により, HMG-CoA が合成される。HMG-CoA は, HMG-CoA 還 元酵素により，メバロン酸に還元される。この還元段階 が，コレステロール合成の律速段階となる。次いで，9 段階の反応を経てコレステロールが合成される。高コレ ステロール症の治療薬として, HMG-CoA 還元酵素阻害 剤が開発されている。HMG-CoA 還元酵素阻害剤を塗布

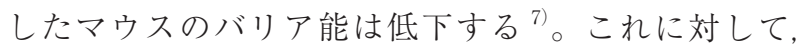
HMG-CoA 還元酵素阻害剂の服用による副作用として, 表皮透過バリア障害は報告されていない。したがって, 血液循環で表皮に輸送され，ケラチノサイトに取り込ま れたコレステロールに比べ，表皮で合成されるコレステ ロールが角層の主要な構成成分となると考えられる。合 成されたコレステロールの一部は脂肪酸エステル化され
コレステロールエステルに，あるいは，硫酸化され，コ レステロール硫酸となる。

\section{$4 \cdot 2$ 脂肪酸合成}

炭素鎖長が, 16 までの脂肪酸は, 脂肪酸合成酵素に より生合成され, それより長鎖の脂肪酸は, 脂肪酸鎖長 延長酵素により産生される。脂肪酸合成酵素は, アシル キャリアタンパク質（ACP）が結合したß-ケトアシル $\mathrm{ACP}$ 合成酵素, B- ケトアシル $\mathrm{ACP}$ 還元酵素, 3- ヒド ロキシアシル $\mathrm{ACP}$ 脱水素酵素とエノイル $\mathrm{ACP}$ 還元酵 素の 4 つの酵素から構成される複合体である。脂肪酸合 成はB-ケトアシル -ACP 合成酵素によるアセチル ACP とマロニル ACP との縮合反応により開始される。生成 したアセトアセチル ACP は, B-ケトアシル ACP 還元 酵素により，3-ヒドロキシブチリル ACP に還元され， 次いで, 3-ヒドロキシアシル ACP 脱水素酵素によりク ロトニル $\mathrm{ACP}$ となっさらに, クロトニル $\mathrm{ACP}$ は, エノイル ACP 還元酵素でブチル $\mathrm{ACP}$ となる。この 4 段階の反応が繰り返され, 炭素鎖長 16 までの脂肪酸が 合成される。

脂肪酸鎖長延長酵素系は, 脂肪酸合成と同様に 4 つの 酵素系によるが, 基質は, ACP と結合せず CoA と結合 している。ELOVL (Elongation of very long chain FAs protein）（乃-ケトアシル CoA 合成酵素）により, 鎖長 延長反応が開始する。脂肪酸の鎖長と飽和度の違いによ る基質特異性がある 7 種類のアイソザイムの ELOVLが 哺乳動物で同定されている ${ }^{8-10)}$ 。表皮は, 全てのアイソ ザイムを発現している。ELOVL1は24より長鎖の炭素 鎖長脂肪酸を合成し，その脂肪酸がELOVL4 の基質と なり，炭素鎖長 26 以上の極長鎖脂肪酸を合成され る $^{11)}$ 。極長鎖の脂肪酸を構成成分とするセラミドは, 表皮の物質透過バリアの構成成分の 1 つである。特に， 極長鎖脂肪酸は，バリア形成に必須な $\omega$ - ヒドロキシア シルセラミドの酸アミド結合型脂肪酸として利用されて いる ${ }^{12)}$. ELOVL1 欠損と ELOVL4 酵素活性を失った変 異 ELOVL4 遺伝子を導入 (ホモ型), あるいは ELOVL4 を欠損したトランスジェニックマウスは, 過剰な水分蒸 散と, その結果起きる体温低下により, 生後数時間で死 ぬ ${ }^{13)}$ 。しかし, これら 2 つ以外の ELOVLは, 基質特 異性が重複していることから, 単独の ELOVL変異, 欠 損による機能異常は, 皮膚で観察されていない。

非水酸基化脂肪酸に加えて, 皮膚は， $\alpha$ または $\omega$ 位 置が水酸基化された脂肪酸を合成する。特に， $\omega$ - ヒド ロキシ脂肪酸は, 分化した表皮のケラチノサイトで産生 され，他の組織の細胞で合成されていない。チトクロー ム P450（CYP）の 4 型の CYP4F22 が, 極長鎖脂肪酸 $\mathrm{CoA}$ を基質として極長鎖脂肪酸の $\omega$ 位を水酸基化す 


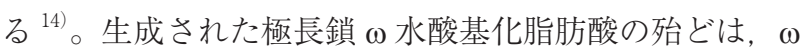
ヒドロキシアシルセラミドと, そのグルコース配糖体, $\omega$ ヒドロキシアシルグルコシルセラミドの合成に使われ る。

\section{$4 \cdot 3$ セラミド合成}

顆粒層で，セラミド産生が高まる。量的だけでなく, 12 分子種からなる他の組織に類を見ない多様な分子種 のセラミドが産生されることが，分化の後期の表皮ケラ チノサイトの特徵である。セラミドは, De novo と Salvage 経路により産生される。

\section{$4 \cdot 3 \cdot 1$ De novo セラミド合成}

De novo セラミド合成は, セリンパルミトイル CoA 転移酵素による L-セリンとパルミトイル CoA の縮合で 始まり，この過程がセラミド合成の律速段階となる。こ の縮合反応で生成した 3- ケトスフィンガニンは，3- ケ トスフィンガニン還元酵素でスフィンガニン（ジヒドロ スフィンゴシン）となり，次いで，七ラミド合成酵素で アミノ基に脂肪酸が結合し，ジヒドロセラミドとなる。 哺乳動物において，脂肪酸鎖長に基質特異性がある 6 種 のアイソザイムのセラミド合成酵素が見出され，表皮は すべてのアイソザイムを含んでいる。殆どのジヒドロセ ラミドは，飽和化酵素（desaturase [DES]）1あるい は 2 で, 各々, スフィンゴシンとフィトスフィンゴシン (4- ヒドロキシスフィンガニン) となる。また, 表皮には, 6- ヒドロキシスフィンゴシン型のセラミドが含まれてい るが，6-ヒドロキシ化の酵素は明らかにされていない。

$\omega$ - ヒドロキシセラミドは， $\omega$ 水酸基化極長鎖脂肪酸 とスフィンゴシン塩基を基質として，七ラミド合成酵素 3 により合成される。 $\omega$ - ヒドロキシアシルセラミドを生 成する。次いで， $\omega$ 位水酸基が脂肪酸（正常な皮膚では 殆どがリノール酸）でアシル化され， ミドが生成される。アシル化に利用される脂肪酸は, 卜 リグリセリドから，CGI-58 というタンパク質により活 性化されたトリグリセリドリパーゼにより加水分解され 生成する ${ }^{15,16)}$ 。トリグリセリドから生成したリノール 酸は, Patatin like phospholipase domain containing 1 により, $\omega$-O-ヒドロキシセラミドの $\omega$ 位水酸基にエス テル結合化され ${ }^{17-19)} ， \omega-\mathrm{O}-$ アシルセラミドの構成成分 となる。

小胞体で合成されたセラミドの殆どは，スフィンゴミ エリン合成酵素とグルコシルセラミド合成酵素により， 各々,スフィンゴミエリンとグルコシルセラミドとなり, 細胞膜と細胞内小胞器官の膜形成に利用される。一部の スフィンゴミエリンとグルコシルセラミドは，分化後期 のケラチノサイトに含まれる層板顆粒（ラメラ顆粒， ラ メラボディ）に輸送される。グルコシルセラミドは
ABCA12 (a sub family of ATP-binding cassette transporter）により輸送されると考えられている ${ }^{20)}$ 。層板顆 粒には，これらスフィンゴ脂質以外に，コレステロール， グリセロリン脂質やタンパク質あるいは脂質加水分解酵 素も含まれる。これらの成分はバリア形成や角層細胞の 剥離に関与する。層板顆粒の内容物が, 細胞内で分解さ れたり，あるいは，内容成分が細胞内に放出されたりは しないと考えられる。したがって, 層板顆粒は角層に必 要な成分を格納し, 角層に届けることを役割とした細胞 内小器官と言えよう。層板顆粒は, 顆粒層から角層に移 行する際, 角層側の細胞膜に融合し, 内容物を角層の細 胞間に放出する。層板顆粒は, 透過型電子顕微鏡観察で 卵形の構造物として観察される ${ }^{21)}$ 。一方，クライオ走 査型電子顕微鏡により, 層板顆粒は細胞質から, 細胞膜 につながる環状細網構造物として観察されている ${ }^{22) 。 ~}$ 三次元電子顕微鏡観察により, 環状細網構造物が確認さ れている ${ }^{23)}$ 。層板顆粒は表皮以外に肺胞に分布し, 肺サ一 ファクタントを貯留している。肺サーファクタントはホ スファチジルコリン (80-90\%) とホスファチジルグリ セロール（5-10％）を含有し，表皮の層板顆粒と内容物 は違っている ${ }^{24)}$ 。

\section{$4 \cdot 3 \cdot 2$ Salvage（スフィンゴシン塩基リサイクル） 経路によるセラミドの合成}

層板顆粒以外に分布するグルコシルセラミドとスフィ ンゴミエリンは, 細胞内でß-グルコセレブロシダーゼ とスフィンゴミエリナーゼにより，七ラミドに代謝され うる。一部のセラミドは, セラミダーゼにより, 脂肪酸 とスフィンゴシン塩基に加水分解され, 再度, セラミド 合成酵素によりセラミドとなる。以下に解説するように 5つのセラミダーゼのアイソザイムが哺乳動物で明らか にされ，ケラチノサイトはすべてのアイソザイムを含 む。各々のアイソザイムは，異なった至適 $\mathrm{pH}$ を持つ。 酸性セラミダーゼ, 中性セラミダーゼ，アルカリ性セラ ミダーゼ 1 ，アルカリ性セラミダーゼ 2 ，フィトスフィ ンゴシン型のセラミドを分解するアルカリ性セラミダー ゼ 3 である。アルカリ性セラミダーゼ 1 は表皮に特異的 に発現する。酸性セラミダーゼとアルカリ性セラミダーゼ 1 は，ケラチノサイトの分化により発現が高まる ${ }^{25,26) 。 一 ~}$ 方, アルカリ性セラミダーゼ 3 は分化により低下し, 中 性セラミダーゼ, アルカリ性セラミダーゼ 1 とアルカリ 性セラミダーゼ 2 は分化で変動しない25, 26)。

グルコシルセラミドとスフィンゴミエリンから生成し たセラミドがセラミダーゼにより分解され産生したス フィンゴシン塩基と多様な分子種の脂肪酸を原料とし て，当初の De novo 合成で生成されなかった分子種の 合成も可能となる ${ }^{27)}$ 。著者はこの経路を“セラミド分子 
のリモデリング経路”と呼称している（Fig. 1）。セラミ ドが分解されることなく蓄積させる層板顆粒とリモデリ ング経路により多様な分子種のセラミドが蓄積されてい くと考えられる。

分化後期 (顆粒層) のケラチノサイトは，鎖長と水酸 基化度が多様性に富む酸アミド結合脂肪酸とスフィンゴ シン塩基の違いにより, 計 12 分子種のセラミドを合成 する（Fig. 2)。酸アミド結合の脂肪酸の種類で N（非水 酸基化), $\mathrm{A}$ ( $\alpha$ 水酸基化), $\mathrm{E}$ ( $\omega$ 水酸基のエステル化), スフィンゴシン塩基の種類で $\mathrm{S}$ (スフィンゴシン), D (ジ ヒドロスフィンゴシン)，6-ヒドロキシスフィンゴシン (H) と略記 L, EOS, EODS, NS, NDS, NP, ADS, $\mathrm{EOH}, \mathrm{AS}, \mathrm{AP}, \mathrm{AH}, \mathrm{NH}$ と $\mathrm{EOP}^{28)}$ の様式で分子種を 記載されている。以前は, EOS, NS, NP, EOH, AS, $\mathrm{AP}, \mathrm{AH}, \mathrm{NH}, \mathrm{EOP}$ 各々, Cer1, Cer2, Cer3, Cer4, Cer5, Cer6, Cer7, Cer8 およびCer9 と命名さ れていた。これらは順相薄層クロマトグラフィー上で移 動度の高い（疎水性の高い）分子種から，低い分子種へ の順による。

\section{$4 \cdot 3 \cdot 3$ バリアセラミドの生成}

セラミドは，表皮透過バリアの形成に重要な役割を果
たしている。生体膜に普遍的に存在するセラミドと異な り，角層のみに含まれ特有な機能を示すセラミドを筆者 は“バリアセラミド”と呼称する。

層板顆粒から，細胞間に放出されたグルコシルセラミ ド，スフィンゴミエリン，コレステロールエステル，グ リセロリン脂質は, 各々の脂質を分解する加水分解酵素 で，七ラミド，脂肪酸，コレステロールとなり，多層膜 （ラメラ）構造を形成し，表皮透過バリアとなる。ラメ ラ構造物にはこれら主要な脂質成分以外に少量成分とし てスフィンゴシンとスフィンガニンが含まれ, これらも， 安定なラメラ構造の形成に寄与している ${ }^{29) 。 ~}$

\section{$4 \cdot 3 \cdot 4$ 結合型セラミドの生成}

$\omega$ - ヒドロキシセラミドの $\omega$ 位の水酸基が, 角化不溶 性膜の細胞間隙側に位置するグルタミン酸／グルタミン に富むぺプチドに共有結合し，角質細胞脂質外膜（Corneocyte lipid-bound envelope, CLE）を形成している。 このタンパク質に結合したセラミドを結合型セラミド, それ以外のセラミドを非結合型セラミドと呼称する。結 合型セラミドの生成は, 以下の 3 段階の過程で生成す

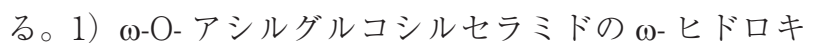

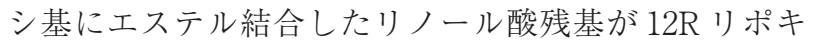

バリアセラミド

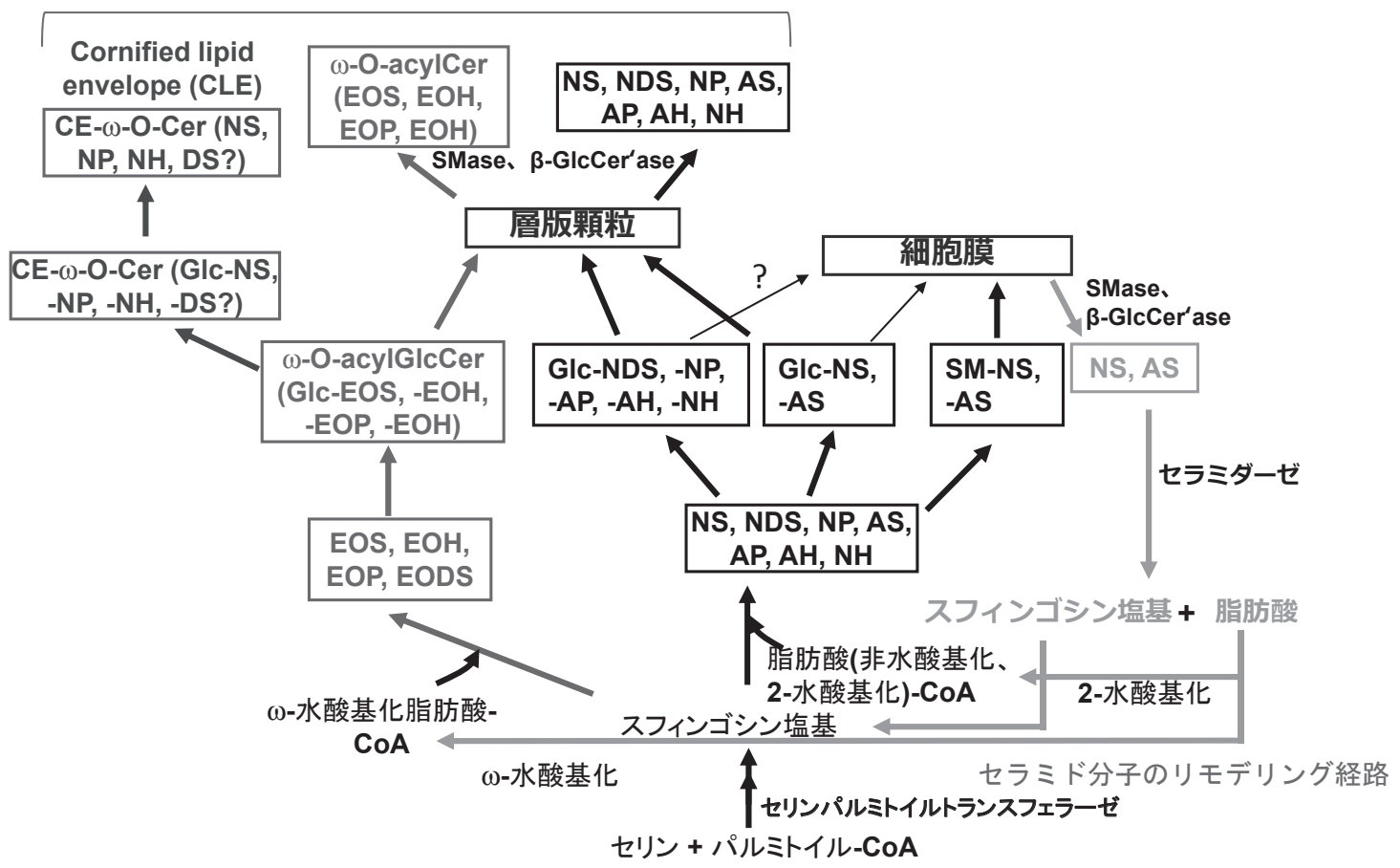

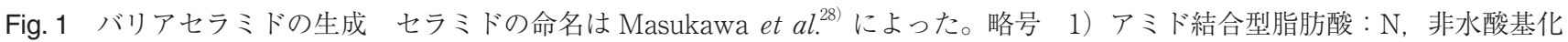
脂肪酸； $\mathrm{A} ， 2$ - 水酸基化脂肪酸。2） スフィンゴシン塩基：D， ジヒドロスフィンゴシン（スフィンガニン）；，スフィン ゴシン；P，フィトスフィンゴシン；H，6-水酸基化スフィンゴシン。幾らかの量の合成された主に NS, AS をセラミド 母骨格とするスフィンゴミエリンとグルコシルセラミドは細胞の主に構成成分となる。これらのスフィンゴミエリンとグ ルコシルセラミドはエンドサイトーシスにより細胞内に取り达まれ, リソゾームでスフィンゴシン塩基と脂肪酸に分解さ れる。生成したスフィンゴシン塩基と脂肪酸は, 再利用され, 様々な分子種のセラミド合成に利用される（リモデリング 経路 ${ }^{56)}$ 。Cer'ase，セラミダーゼ；CE，角化不溶性膜；GlcCer'ase，ß-グルコシルセラミダーゼ。 


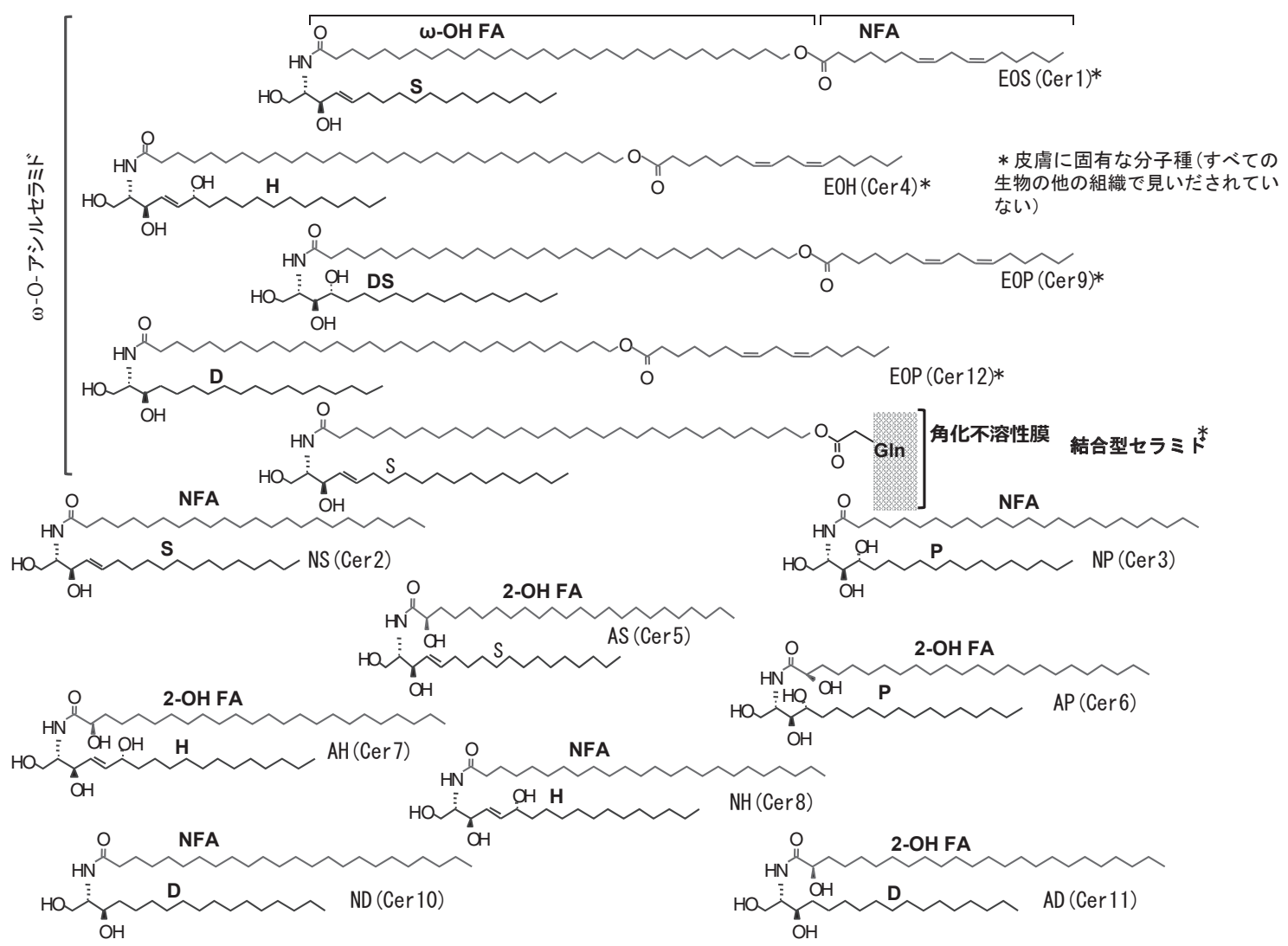

Fig. 2 多様な分子から構成されるバリアセラミド

シゲナーゼ (12R-LOX)，または，リポキシゲナーゼ 3 により過酸化体となる ${ }^{30)}$ 。2）この酸化体が酵素的に角 化不溶性膜に結合する。トランスグルタミナーゼIが, $\omega$-ヒドロキシセラミドの角化不溶性膜への結合に関与 する酵素であると報告されている ${ }^{31)}$ 。しかし, トラン スグルタミナーゼ I 遺伝子が変異し, 酵素活性が痕跡程 度のラメラ魚鱗癬の患者角層においてもCLE は形成さ れている ${ }^{32)}$ れしたがって，トランスグルタミナーゼ I 以外の酵素も結合型セラミドの形成に関与していると考 えられる。次いで，3）ß-グルコシセレブロシダーゼに より, 糖鎖が切断され, 角化不溶性膜 -O- セラミドとな る。一部の角化不溶性膜 - O- セラミドは, さらにセラミ ダーゼにより，七ラミド部分が加水分解され，角化不溶 性膜 - O- 極長鎖脂肪酸となる。

角層に含まれる計 12 種のセラミドのすべての分子種 は, グルコシルセラミドから産生され，2種がスフィン ゴミエリン（NS, AS）から産生される (Fig. 1) ${ }^{21,22) 。 ~}$

\section{5 表皮透過バリアの構造物}

コレステロール，遊離脂肪酸とセラミドが主要脂質と なり，角層の細胞間でラメラ (多層) 膜構造物を形成す る。これら脂質のモル比率は $1: 1: 1$ である。セラミド の分子量がコレステロールあるいは脂肪酸に比べて大き
いため, セラミドの重量比は全体の $50 \%$ を占めてい る ${ }^{33)}$ 。これら主要脂質でラメラ膜構造物は形成されるが, それ以外にもスフィンゴシン塩基がラメラ構造物の形成 に関与していると考えられる ${ }^{29)}$ 。また，未解明の脂質 や疎水性のペプチドも膜構造物成分として含まれている 可能性がある。

電子顕微鏡観察で角層の微細構造を可視化することが 出来る。還元オスミウム染色とルテニウム染色切片の透 過型電子顕微鏡下で層版顆粒, 同顆粒の細胞膜への融合 と, 角層細胞間への放出と角層ラメラ構造帯を含めた表 皮の構造を観察することが出来る ${ }^{34)}$ 。また, 走査電子顕 微鏡で皮膚を含め構造物の表面形状の観察ができる ${ }^{35)}$ 。 角層のテープ剥離を組み合わせた走査電子顕微鏡観察に より，違った深度の角層の表面形状が把握される ${ }^{35)} 。$ さらに, 未固定で含水状態の皮膚に急速凍結割断法（ク ライオ - 走査電子顕微鏡）を用いると, 皮膚の横断面の 観察が可能となる ${ }^{35)}$ 。走査電子顕微鏡の場合, ラメラ 構造の観察は出来ないものの, 未固定, 未脱水試料を用 いるため, 水の局在を含め, より生体に近い状態の微細 構造の観察が可能である。

$\mathrm{X}$ 線回析法, 中性子線回析法, フーリ工変換赤外線解 析（FT-IR）および示差熱系解析により, さらに, 詳細 な角層のラメラ構造の性状が明らかとなってきた。二次 
元的 X 線回析で, ラメラ構造は長周期 $(13 \mathrm{~nm})$ と短周 期 $(6 \mathrm{~nm})$ の二つの層から形成されていることが明ら かとなっている ${ }^{36)}$ 。長周期と短周期以外に, 乱れたラ メラ構造物の存在が指摘されている ${ }^{37)}$ 。また, 三次元 的な X 線解析でラメラ構造物の充填構造が検討され, 六方晶 (hexagonal) と斜方晶 (orthorhombic) 状態が あることが明らかにされた ${ }^{38)}$ 。六方晶に比べて，斜方 晶は充填密度がより高く, 物質透過度が低下する。X 線 ビーム速度を低下させた low flux electron X 線回析法 から，充填間隔の異なる二種の斜方晶が存在することも 解明されている ${ }^{39)}$ 。さらに, 湿度に呼応して, ラメラ 構造物が膨潤することから，ラメラ構造物内に水が含ま れると考えられている ${ }^{40)}$ 。

\section{6 脂質が原因となり，表皮透過バリア機能に異常がで きる皮膚疾患}

アトピー性皮膚炎, 乾癬や魚鱗癬において, 表皮透過 バリア機能が低下していることから, それら表皮や角層 の脂質組成分析がなされてきた。遺伝性の常染色体劣性 先天性魚鱗癬に見られるように特定の脂質分子の合成酵 素の遺伝子変異によらない, アトピー性皮膚炎, 乾癬, あるいは加齢における，脂質の組成変化の原因は明らか になっていない。また, 常染色体劣性先天性魚鱗癬を含 めて, 特定の脂質合成の欠損が起きた場合, 代償的に他 の脂質成分の合成も変わる。したがって, 形態や機器分 析から得られた角層構造の変化の原因を調べるために は，単一の脂質分子種だけでなく角層成分を総合的に検 証する必要がある。

媒体を通じて“アトピー性皮膚炎においてセラミドは減 少する”との必ずしも正確とは言い難い情報が伝わってい る。アトピー性皮膚炎は, 多様な病因により生じる。一部 のアトピー性皮膚炎患者の皮膚において，セラミド／ コレステロールの比率が低下 ${ }^{41}{ }^{42}$ ， セラミド分子種の うち, EOS, NP, NHの低下と NS, AS, AH, AP, ADS

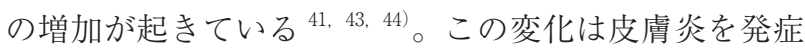
していない角層で起きているが, 皮膚炎を発症した皮膚 部位では顕著となる。さらに, 短鎖遊離脂肪酸 (18 以下) と短鎖セラミド (42 以下 [酸アミド結合型脂肪酸とス フィンゴシン塩基の合計） が増加し，逆に，それらよ り長鎖の遊離脂肪酸とセラミドが減少する。また，モノ 不飽和遊離脂肪酸の増加も明らかにされている ${ }^{43-46) 。 ~}$ スフィンゴミエリンの酸アミド結合型脂肪酸を解離する スフィンゴミエリンデアシラーゼ活性が，アトピー性皮 膚炎患者表皮で高まることが報告されている ${ }^{47,48)}$ 。ス フィンゴミエリンデアシラーゼはグルコシルセラミドの 酸アミド結合型脂肪酸も解離するとされている ${ }^{47)}$ 。し
かし，グルコシルセラミド合成酵素欠損マウスにおいて スフィンゴミエリンからの EOS 産生は確認されている ものの，通常はスフィンゴミエリンから EOS は産生さ れない ${ }^{49)}$ 。精製された酵素で, その基質特異性の解明 が必要である。したがって, 現時点で, 同酵素での特定 のセラミド分子種組成の変化は説明されない。セラミド の産生減少については, アトピー性皮膚炎で起きる Th2 型 の炎症性サイトカインによることが報告されている ${ }^{50,51) 。 ~}$

\section{7 脂質メディエーター}

プロスタノイド，ロイコトリエン，レゾルビン，リゾ リン脂質, カンナビノイドなどの脂質は, 細胞や組織の 機能を調節, 影響を与える脂質生物（生理）活性を示し, 脂質メディエーターと呼称されている。脂質メディエー ターは, 定常状態で存在していたとしても, 少量である。 刺激（酸化ストレス, 感染, サイトカイン, キモカイン, ホルモン他）に反応して, 細胞の特定の場所（細胞膜な ど）で定常状態に比べ，少量ではあるが有意に増加する ことで生理活性を示す。脂質メディエーターは，3つに 分類されている（Table 1)。

クラス 1 にはプロスタノイド，ロイコトリエンが, ク ラス 2 にはリゾリン脂質 血小板活性化因子 [PAF], リゾホスファチジン酸, スフィンゴシン -1-リン酸, が, クラス 3 にはオメガ -3 高度不飽和脂肪酸由来の抗炎症 脂質 [レゾルビン］があげられる。脂質メディエーター が, どのような細胞内情報伝達系を経て, 特定の生理活 性を示すかという事, 並びに, 生理活性を示す濃度䦨值 が, 細胞, 刺激, 脂質の種類などにより異なっている。

3 つのクラスの脂質メディエーター以外の脂質も, 情 報伝達物資として, 細胞の機能に影響をあたえる脂質が あり，セラミドもその 1 つである。酸化ストレスを受け た細胞において, セラミドの産生が高まる。細胞内で増 加したセラミドは, 細胞の増殖を抑制する。セラミド量 の増加が大きい場合, 細胞死が誘導される。著者らは, 細胞死を誘導しない程度の紫外線照射, 紫外線以外の酸 化ストレス（過酸化物, 酸素ラジカル), あるいは表皮 透過バリア機能の低下により，小胞体ストレスが誘導さ れ，その結果，カテリシジン抗菌ペプチドの産生が高ま ることを見出した。その機構を検討した結果, これらス トレスでセラミドの生成が高まり，その代謝産物のス フィンゴシン -1-リン酸増加が脂質メディエーターとし て, カテリシジン抗菌ペプチドの転写を高めることを明 らかにした ${ }^{52-54)}$ 。興味深いことに, 同様な経路で産生 の高まったセラミドの代謝産物のセラミド-1-リン酸が, 全く違った作用機構で, $\beta$ - ディフェンシン 2 と $\beta$ - ディ

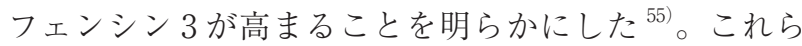


Table 1 脂質メディエーター

\begin{tabular}{|c|c|c|}
\hline 脂質メディエーター & 生理活性 & 皮膚疾患 \\
\hline PGE2 & $\begin{array}{l}\uparrow \text { 細胞増殖, } \uparrow \text { 細胞分化 } \\
\uparrow \text { 細胞遊走性 } \\
\uparrow \text { メラニン産生 } \\
\text { T 細胞活性化 }\end{array}$ & $\begin{array}{l}\text { 接触過敏症 }{ }^{56)} \text {, 乾癬 }{ }^{56)} \text {, 創傷治癒 }{ }^{57)} \text {, } \\
\text { メラノーマ以外の皮膚癌 }{ }^{88)}\end{array}$ \\
\hline 15d-PGJ2 & 个佊脂合成 ${ }^{59)}$, 抗炎症 ${ }^{60)}$ & ニキビ?, 脂漏症? \\
\hline エンドカンナビノイド & $\begin{array}{l}\downarrow \text { 細胞増殖, } \downarrow \text { 皮脂合成, } \\
\text { 抗炎症 } 61 \text { ) }\end{array}$ & \\
\hline スフィンゴシン -1- リン酸 & $\begin{array}{l}\text { 抗炎症 }{ }^{62)}, \uparrow \text { ^カリシジ } \\
\text { ン抗菌ペプチド産生 }{ }^{52)}\end{array}$ & $\begin{array}{l}\text { アトピー性皮膚炎：」スフィンゴシン } \\
\text {-1- リン酸濃度 }\end{array}$ \\
\hline セラミド -1-リン酸 & $\begin{array}{l}\text { ^ヒト抗菌ペプチド ß-デ } \\
\text { フィンシン } 2 \& 3 \text { 産生 }\end{array}$ & \\
\hline $\begin{array}{l}\text { GM3, GD3, 9-O-acetyl } \\
\text { GD3 and GD1b }\end{array}$ & $\begin{array}{l}\text { ケラチノサイト } \\
\text { ケ分化 }{ }^{65)}\end{array}$ & \\
\hline
\end{tabular}

の抗菌ペプチドは, 顆粒層以下のケラチノサイトで産生 されるが, 角層（おそらく細胞間）に移行し，角層の抗 菌バリアを形成する。このようにセラミドは，表皮透過 バリアの形成に加えて，代謝産物のスフィンゴシン -1リン酸とセラミド-1-リン酸を通じて，抗菌バリアの形 成にも寄与している。

\section{8 おわりに}

1970 年以降に陸棲哺乳動物の表皮脂質の解析が着手 された。角層の脂質が表皮透過バリアの重要な成分であ ること，また，角層のセラミドの特異性（量と分子種多 様性）が明らかになった。さらに，1990年以降に表皮 透過バリアが低下しているアトピー性皮膚炎の皮膚でセ ラミドの分子種組成や総量が低下することが明らかに なったこともあり，皮膚の乾燥対策用スキンケア製品に セラミドが配合されるに至った。また，機能性食品素材 として，セラミドやスフィンゴ脂質の利用も始まってい る。さらに，著者らが明らかにしたように，セラミドの 代謝産物は抗菌ペプチド産生を調節するメデイエーター としての役割をも持つ。本総説の前半でまとめたように， 皮膚のバリアは, 全身の組織・器官の健常性維持にもつ ながることから, 今後, 益々, セラミドを含めて脂質成 分は，スキンケアを目的として，利用されていくものと 考えられる。

\section{文 献}

1) Samuels L., Kunst L, Jetter R. Sealing plant surfaces: cuticular wax formation by epidermal cells. Annu. Rev. Plant Biol. 59, 683-707 (2008).

2) Rice RH, Green $H$. The cornified envelope of terminally differentiated human epidermal keratinocytes consists of cross-linked protein. Cell 11, 417-422 (1977).

3) Oesch F, Fabian E, Oesch-Bartlomowicz B et al. Drug- metabolizing enzymes in the skin of man, rat, and pig. Drug Metab. Rev. 39, 659-698 (2007).

4) Hall K, Lee TH, Mechler AI et al. Real-time measurement of membrane conformational states induced by antimicrobial peptides: balance between recovery and lysis. Sci. Rep. 4, 5479 (2014).

5) Brogden KA. Antimicrobial peptides: pore formers or metabolic inhibitors in bacteria? Nat. Rev. Microbiol. 3, 238-250 (2005).

6) Scharschmidt TC, Vasquez KS, Truong HA et al. A wave of regulatory $\mathrm{T}$ cells into neonatal skin mediates tolerance to commensal microbes. Immunity 43, 10111021 (2015).

7) Feingold KR, Man MQ, Menon GK et al. Cholesterol synthesis is required for cutaneous barrier function in mice. J. Clin. Invest. 86, 1738-1745 (1990).

8) Jakobsson A, Westerberg R, Jacobsson A. Fatty acid elongases in mammals: their regulation and roles in metabolism. Prog. Lipid Res. 45, 237-249 (2006).

9) Ohno Y, Suto S, Yamanaka M et al. ELOVL1 production of C24 acyl-CoAs is linked to C24 sphingolipid synthesis. Proc. Natl. Acad. Sci. USA 107, 18439-18444 (2010).

10) Guillou H, Zadravec D, Martin PG et al. The key roles of elongases and desaturases in mammalian fatty acid metabolism: Insights from transgenic mice. Prog. Lipid Res. 49, 186-199 (2010).

11) Uchida $Y$. The role of fatty acid elongation in epidermal structure and function. Dermatoendocrinol. 3, 65-69 (2011).

12) Vasireddy V, Uchida Y, Salem N, Jr. et al. Loss of functional ELOVL4 depletes very long-chain fatty acids $(>=\mathrm{C} 28)$ and the unique\{omega\}-O-acylceramides in skin leading to neonatal death. Hum. Mol. Genet. 16, 471-482 (2007).

13) Vasireddy V, Wong P, Ayyagari R. Genetics and molecular pathology of Stargardt-like macular degeneration. Prog. Retin. Eye Res. 29, 191-207 (2010).

14) Ohno Y, Nakamichi S, Ohkuni A et al. Essential role of 
the cytochrome P450 CYP4F22 in the production of acylceramide, the key lipid for skin permeability barrier formation. Proc. Natl. Acad. Sci. USA 112, 77077712 (2015).

15) Uchida Y, Cho Y, Moradian S et al. Neutral lipid storage leads to acylceramide deficiency, likely contributing to the pathogenesis of Dorfman-Chanarin syndrome. J. Invest. Dermatol. 130, 2497-2499 (2010).

16) Radner FP, Streith IE, Schoiswohl G et al. Growth retardation, impaired triacylglycerol catabolism, hepatic steatosis, and lethal skin barrier defect in mice lacking comparative gene identification-58 (CGI-58). J. Biol. Chem. 285, 7300-7311 (2010)

17) Grond S, Eichmann TO, Dubrac S et al. PNPLA1 deficiency in mice and humans leads to a defect in the synthesis of Omega-O-acylceramides. J. Invest. Dermatol. 137, 394-402 (2017).

18) Hirabayashi $T$, Anjo $T$, Kaneko A et al. PNPLA1 has a crucial role in skin barrier function by directing acylceramide biosynthesis. Nat. Commun. 8, 14609 (2017).

19) Ohno $Y$, Kamiyama N, Nakamichi $\mathrm{S}$ et al. PNPLA1 is a transacylase essential for the generation of the skin barrier lipid omega-O-acylceramide. Nat. Commun. 8, 14610 (2017)

20) Akiyama M, Sugiyama-Nakagiri $Y$, Sakai K et al. Mutations in lipid transporter ABCA12 in harlequin ichthyosis and functional recovery by corrective gene transfer. J. Clin. Invest. 115, 1777-1784 (2005).

21) Elias PM. Lipid abnormalities and lipid-based repair strategies in atopic dermatitis. Biochim. Biophys. Acta 1841, 323-330 (2014).

22) Ishida-Yamamoto A, Simon M, Kishibe M et al. Epidermal lamellar granules transport different cargoes as distinct aggregates. J. Invest. Dermatol. 122, 1137-1144 (2004)

23) den Hollander L, Han H, de Winter M et al. Skin lamellar bodies are not discrete vesicles but part of a tubuloreticular network. Acta Derm. Venereol. 96, 303-308 (2016).

24) Schmitz G, Müller G. Structure and function of lamellar bodies, lipid-protein complexes involved in storage and secretion of cellular lipids. J. Lipid Res. 32, 15391570 (1991).

25) Houben E, Holleran WM, Yaginuma T et al. Differentiation-associated expression of ceramidase isoforms in cultured keratinocytes and epidermis. J. Lipid Res. 47, 1063-1070 (2006).

26) Lin TK, Crumrine D, Ackerman LD et al. Cellular changes that accompany shedding of human corneocytes. J. Invest. Dermatol. 132, 2430-2439 (2012).

27) Hamanaka S, Nakazawa S, Yamanaka M et al. Glucosylceramide accumulates preferentially in lamellar bodies in differentiated keratinocytes. Br. J. Dermatol. 152, 426-434 (2005).

28) Masukawa Y, Narita H, Shimizu E et al. Characterization of overall ceramide species in human stratum cor- neum. J. Lipid Res. 49, 1466-1476 (2008).

29) Loiseau N, Obata Y, Moradian S et al. Altered sphingoid base profiles predict compromised membrane structure and permeability in atopic dermatitis. J. Dermatol. Sci. 72, 296-303 (2013).

30) Zheng $\mathrm{Y}$, Yin H, Boeglin WE et al. Lipoxygenases mediate the effect of essential fatty acid in skin barrier formation: a proposed role in releasing omega-hydroxyceramide for construction of the corneocyte lipid envelope. J. Biol. Chem. 286, 24046-24056 (2011).

31) Nemes $Z$, Marekov LN, Fésüs L et al. A novel function for transglutaminase 1: attachment of long-chain omega-hydroxyceramides to involucrin by ester bond formation. Proc. Natl. Acad. Sci. USA 96, 8402-8407 (1999).

32) Elias PM, Schmuth M, Uchida Y et al. Basis for the permeability barrier abnormality in lamellar ichthyosis. Exp. Dermatol. 11, 248-256 (2002).

33) Man MM, Feingold KR, Thornfeldt CR et al. Optimization of physiological lipid mixtures for barrier repair. $J$. Invest. Dermatol. 106, 1096-1101 (1996).

34) Menon GK, Grayson S, Elias PM. Ionic calcium reservoirs in mammalian epidermis: ultrastructural localization by ion-capture cytochemistry. J. Invest. Dermatol. 84, 508-512 (1985).

35) Fatouros DG, Groenink HW, de Graaff AM et al. Visualization studies of human skin in vitro/in vivo under the influence of an electrical field. Eur. J. Pharm. Sci. 29, 160-170 (2006).

36) Charalambopoulou GC, Steriotis TA, Mitropoulos AC et al. Investigation of water sorption on porcine stratum corneum by very small angle neutron scattering. J. Invest. Dermatol. 110, 988-990 (1998).

37) Hatta I. Skin bioscience structure and function of stratum corneum. J. Adhesion Soc. Jpn. 52, 145-151(2016).

38) Bouwstra JA, Honeywell-Nguyen PL, Gooris GS et al. Structure of the skin barrier and its modulation by vesicular formulations. Prog. Lipid Res. 42, 1-36, (2003).

39) Nakazawa H, Imai T, Hatta I et al. Low-flux electron diffraction study for the intercellular lipid organization on a human corneocyte. Biochim. Biophys. Acta 1828, 1424-1431 (2013).

40) Nakazawa H, Ohta N, Hatta I. A possible regulation mechanism of water content in human stratum corneum via intercellular lipid matrix. Chem. Phys. Lipids 165, 238-243 (2012).

41) Di Nardo A, Wertz P, Giannetti A et al. Ceramide and cholesterol composition of the skin of patients with atopic dermatitis. Acta Derm. Venereol. 78, 27-30 (1998).

42) Angelova-Fischer I, Mannheimer AC, Hinder A et al. Distinct barrier integrity phenotypes in filaggrin-related atopic eczema following sequential tape stripping and lipid profiling. Exp. Dermatol. 20, 351-356 (2011).

43) Imokawa G, Abe A, Jin K et al. Decreased level of ceramides in stratum corneum of atopic dermatitis: an 
etiologic factor in atopic dry skin? J. Invest. Dermatol. 96, 523-526 (1991)

44) Bleck $\mathrm{O}$, Abeck $\mathrm{D}$, Ring J et al. Two ceramide subfractions detectable in Cer (AS) position by HPTLC in skin surface lipids of non-lesional skin of atopic eczema. J. Invest. Dermatol. 113, 894-900 (1999).

45) Janssens M, van Smeden J, Gooris GS et al. Increase in short-chain ceramides correlates with an altered lipid organization and decreased barrier function in atopic eczema patients. J. Lipid Res. 53, 2755-2766 (2012).

46) Thakoersing VS, van Smeden J, Mulder AA et al. Increased presence of monounsaturated fatty acids in the stratum corneum of human skin equivalents. $J$. Invest. Dermatol. 133, 59-67 (2013).

47) Higuchi K, Hara J, Okamoto R et al. The skin of atopic dermatitis patients contains a novel enzyme, glucosylceramide sphingomyelin deacylase, which cleaves the $\mathrm{N}$-acyl linkage of sphingomyelin and glucosylceramide. Biochem. J. 350 Pt 3, 747-756 (2000).

48) Hara J, Higuchi K, Okamoto R et al. High-expression of sphingomyelin deacylase is an important determinant of ceramide deficiency leading to barrier disruption in atopic dermatitis. J. Invest. Dermatol. 115, 406413 (2000).

49) Amen N, Mathow D, Rabionet M et al. Differentiation of epidermal keratinocytes is dependent on glucosylceramide: ceramide processing. Hum. Mol. Genet. 22, 4164-4179 (2013).

50) Sawada E, Yoshida N, Sugiura A et al. Th1 cytokines accentuate but Th2 cytokines attenuate ceramide production in the stratum corneum of human epidermal equivalents: an implication for the disrupted barrier mechanism in atopic dermatitis. J. Dermatol. Sci. 68, 25-35 (2012).

51) Hatano $Y$, Terashi H, Arakawa $\mathrm{S}$ et al. Interleukin-4 suppresses the enhancement of ceramide synthesis and cutaneous permeability barrier functions induced by tumor necrosis factor-alpha and interferon-gamma in human epidermis. J. Invest. Dermatol. 124, 786-792 (2005).

52) Park K, Elias PM, Shin KO et al. A novel role of a lipid species, sphingosine-1-phosphate, in epithelial innate immunity. Mol. Cell Biol. 33, 752-762 (2013).

53) Park K, Ikushiro H, Seo HS et al. ER stress stimulates production of the key antimicrobial peptide, cathelicidin, by forming a previously unidentified intracellular S1P signaling complex. Proc. Natl. Acad. Sci. USA 113, E1334-1342 (2016).

54) Park K, Elias PM, Oda Y et al. Regulation of Cathelicidin Antimicrobial Peptide Expression by an Endoplasmic Reticulum (ER) Stress Signaling, Vitamin D Re- ceptor-independent Pathway. J. Biol. Chem. 286, 34121-34130 (2011).

55) Kim YI, Park K, Kim JY et al. An endoplasmic reticulum stress-initiated sphingolipid metabolite, ceramide1-phosphate, regulates epithelial innate immunity by stimulating beta-defensin production. Mol. Cell Biol. 34, 4368-4378 (2014).

56) Kawahara K, Hohjoh H, Inazumi $\mathrm{T}$ et al. Prostaglandin E2-induced inflammation: Relevance of prostaglandin E receptors. Biochim. Biophys. Acta 1851, 414-421 (2015).

57) Su WH, Cheng MH, Lee WL et al. Nonsteroidal anti-inflammatory drugs for wounds: pain relief or excessive scar formation? Mediators Inflamm. 2010, 413238 (2010).

58) Rundhaug JE, Simper MS, Surh I et al. The role of the EP receptors for prostaglandin E2 in skin and skin cancer. Cancer Metastasis Rev. 30, 465-480 (2011).

59) Iwata $C$, Akimoto $N$, Sato $T$ et al. Augmentation of lipogenesis by 15-deoxy-Delta12,14-prostaglandin J2 in hamster sebaceous glands: identification of cytochrome P-450-mediated 15-deoxy-Delta12,14-prostaglandin J2 production. J. Invest. Dermatol. 125, 865-872 (2005).

60) Garcia-Bueno B, Madrigal JL, Lizasoain I et al. The anti-inflammatory prostaglandin 15d-PGJ2 decreases oxidative/nitrosative mediators in brain after acute stress in rats. Psychopharmacology (Berl) 180, 513522 (2005).

61) Biro T, Toth BI, Hasko G et al. The endocannabinoid system of the skin in health and disease: novel perspectives and therapeutic opportunities. Trends Pharmacol. Sci. 30, 411-420 (2009).

62) Reines I, Kietzmann M, Mischke R et al. Topical application of sphingosine-1-phosphate and FTY720 attenuate allergic contact dermatitis reaction through inhibition of dendritic cell migration. J. Invest. Dermatol. 129, 1954-1962 (2009).

63) Baumer W, Rossbach K, Mischke R et al. Decreased concentration and enhanced metabolism of sphingosine-1-phosphate in lesional skin of dogs with atopic dermatitis: disturbed sphingosine-1-phosphate homeostasis in atopic dermatitis. J. Invest. Dermatol. 131, 266-268 (2011).

64) Paller AS, Arnsmeier SL, Alvarez-Franco M et al. Ganglioside GM3 inhibits the proliferation of cultured keratinocytes. J. Invest. Dermatol. 100, 841-845 (1993).

65) Paller AS, Arnsmeier SL, Fisher GJ et al. Ganglioside GT1b induces keratinocyte differentiation without activating protein kinase C. Exp. Cell Res. 217, 118-124 (1995). 